\title{
Comparative Study of Soil Nutrient Status at Onigambari Forest Reserve, Oyo State,
} Nigeria

\section{${ }^{* 1}$ ISIENYI, NC; ${ }^{1}$ IHEDIUCHE, CI; ${ }^{2}$ AKINYEMI, GO; ${ }^{3}$ WOGHIREN, AI; ${ }^{1}$ OLUWAPONLE, AI}

\author{
${ }^{* 1}$ Department of Soils and Tree Nutrition, Forestry Research Institute of Nigeria, \\ ${ }^{2}$ Onigambari Research Station, Forestry Research Institute of Nigeria \\ ${ }^{3}$ Department of Forest Conservation and Protection, Forestry Research Institute of Nigeria (FRIN), P. M. B. 5054, Forestry Hill, Jericho, \\ Ibadan, Nigeria. \\ *Corresponding Author: isienyi.nc@frin.gov.ng, Tel: +2348037770485
}

\begin{abstract}
This experiment examined the impact of management techniques for sustaining the forest soils nutrient status using a comparative study of soil chemical and physical properties of different forest types in Onigambari Forest-Reserve. Soil sampling was conducted in two sections representing two forest types; Tectona grandis (TG) plots and the natural vegetation (NV) within Onigambari ForestReserves. Each section, segmented into a $10 \mathrm{~m}$-by- $10 \mathrm{~m}$ quadrat size. Twenty samples were collected at random in each plot in quadruplicate from the surface $(0-15 \mathrm{~cm})$ and subsurface $(15-30 \mathrm{~cm})$ depth. The composite samples were air-dried, prepared for physical and chemical analyses. Data collected were subjected to ANOVA, means were compared using student's t-test $(\mathrm{p} \leq 0.05)$ using JMP Pro 14. The results showed that the means of chemical and physical properties in both forest plantations varied with depth. The $\mathrm{pH}$ increases with depth from 5.95 to 6.15 in TG and 6.15 to 6.25 in NV forest at $0-15 \mathrm{~cm}$ and 15 $30 \mathrm{~cm}$, respectively. However, NV had the highest amounts of organic carbon content, Total-Nitrogen, and exchangeable cations decreased with depth at both forests. Phosphorus content increased from 9.43(0$15 \mathrm{~cm})$ to $10.95(15-30 \mathrm{~cm})$ at TG forest and $2.7(0-15 \mathrm{~cm})$ to $5.9(15-30 \mathrm{~cm})$. Sand content was higher at the TG forest, while higher clay and silt contents were observed in NV. Organic-matter and organic-carbon content were observed to be higher in the surface layer compared to the sub-surface layer in both forests studied. In conclusion, the Natural vegetation soils possess more nutrients than Tectona grandis soils. Therefore, afforestation should be encouraged.
\end{abstract}

\section{DOI: https://dx.doi.org/10.4314/jasem.v25i12.6}

Copyright: Copyright $\odot 2021$ Isienyi et al. This is an open access article distributed under the Creative Commons Attribution License (CCL), which permits unrestricted use, distribution, and reproduction in any medium, provided the original work is properly cited.

Dates: Received: 22 August 2021; Revised: 17 September 2021; Accepted: 06 October 2021

Keywords: Tectona grandis. Natural forest, Onigambari, Vegetation.

Soils physical properties that includes texture, structure, porosity, density, aeration, temperature, water retention, and movement which can be modified by series of operations within the forest environment such as harvesting operations, shifting cultivation, and forest fires develop under natural conditions by the influence of permanent vegetation over a long period of time and thus affects every aspect of soil fertility and productivity because of its influence at determining the ease of root penetration (Oswald, 2013). Forest soils have important indices of the chemical behavior which consist of $\mathrm{pH}$, cationexchange capacity (CEC), anion-exchange capacity (AEC), base saturation (BS) percentage, exchangeable sodium percentage (ESP), electrical conductivity, and redox potential which characterize the forest soils and affect the growth and distribution of forest tree species. Studies have shown that there remain only a few landscapes on Earth which are currently in their natural state (Opeyemi, 2008). Due to anthropogenic activities, the Earth' surface is being significantly altered and the presence of man on the Earth and his use of land has had a profound effect upon the natural environment (Haque and Basak, 2017; Njike, et al. 2011). As a result, since the early 1980s, vast transformations have occurred in the land use and land cover patterns as evidenced by persistent expansion in cultivated land, decrease in natural woodland and grassland in the world (Emenyonu et al, 2015; Njike, et al. 2011). It can therefore be stated that the land use and land cover pattern of a region is an outcome of natural and socio-economic factors and their utilization by man in time and space. This situation is worsened by the lack of information about the potential of land which results in land management model that is not relevant to the suitability and socioeconomic conditions of the society (FAO, 2011; Thuo, 2013). In the same vein, competition for land is 
becoming intense with the continuous rise in human population and urbanization with continuous use of land for agricultural activities year after year (Agyarko, et al., 2014). In recognition of the current global food crises, Nigeria currently pursues policy of expanding the land area under cultivation without deforestation and negative influence on the ecosystem as well as intensifying crop productions by continuous cropping system of which certain arable crops due to their importance globally are included (Nwite, et al., 2017). Therefore, adoption of more sustainable strategies for the maintenance of soil fertility under such conditions becomes imperative to sustain crop yield. It is therefore imperative to understand the influence of tree species on nutrient status of forest soils and other properties. The specific objective of this study is to suggest the management technique needed to sustain the nutrient status of the forest soils.

\section{MATERIALS AND METHODS}

Study Area: This study was carried out in Onigambari Forest Reserve. This is a tropical deciduous lowlands forest and characterized by undulating topography, lying at an altitude between $90 \mathrm{~m}$ and $140 \mathrm{~m}$ above sea level. It is situated in the southern part of Ibadan, Nigeria. It is bounded on the west by River Ona and the east by the main road of Ibadan to Ijebu-ode, located on latitude $7025^{\prime}$ and $7055^{\prime} \mathrm{N}$, longitude 30 53' and 30 9'E. Onigambari Forest Reserve covers a land area of about 17,984ha, which is divided into natural and plantation forests. The natural forest is made up of indigenous species such as Irvingia garbonensis, Treculia africana, Terminalia spp, Triplochiton scleroxylon, among others while the latter consists mainly of exotic species such as Gmelina arborea and Tectona grandis. The annual rainfall ranges between $1200 \mathrm{~mm}$ to $1300 \mathrm{~mm}$ from March to November, while the dry season is from December to February with low relative humidity and an average annual temperature of $26.40 \mathrm{C}$ (Akinyemi et al., 2012; Larinde and Olasupo, 2011; Aluko, 1993).

Soil sampling: Soil samplings were conducted in two compartments representing two forest types; Tectona grandis plots and the natural vegetation in Onigambari Forest Reserves. Each plot was segmented into $10 \mathrm{~m}$ by $10 \mathrm{~m}$ quadrat size, twenty samples were taken at random in each plot from the surface $(0$ to $15 \mathrm{~cm})$ and subsurface $(15$ to $30 \mathrm{~cm})$ depth. The composite samples were air-dried, ground, and passed through a $2 \mathrm{~mm}$ sieve for laboratory analyses.

Laboratory Analysis: Particle size was determined using the improved hydrometer method by Bouyocous (1962). The $\mathrm{pH}$ was determined electrometrically using a glass electrode in a soil-water suspension (a ratio of 1: 2 soil: water). Total nitrogen was determined by the micro Kjeldahl method, according to Bremner (1965). The organic matter content of the soil was determined using the chromic acid digestion method (Walkley and Black, 1934). Phosphorus was extracted by the Bray 1 method (Bray and Kurtz, 1945) and determined by the vanadomolybdate method. Exchangeable $\mathrm{Ca}, \mathrm{Mg}, \mathrm{K}$ and $\mathrm{Na}$ were extracted with $1 \mathrm{~N}$ NH4OAC. Potassium and $\mathrm{Na}$ were determined using flame photometers, while atomic absorption spectrophotometer was used to determine $\mathrm{Ca}$ and $\mathrm{Mg}$. Iron, $\mathrm{Zn}$, and $\mathrm{Mn}$ were extracted in $1 \mathrm{~N} \mathrm{NH4OAC}$ while Copper was extracted using a mixture of $1 \mathrm{~N}$ NH4OAC and 0.01 M EDTA (Ellis, 1968; Osiname, 1972) and determined using atomic absorption spectrophotometer.

Data Analysis: Result generated from the laboratory analysis was subjected to analysis of variance (ANOVA), and the means were compared using student's t-test using JMP PRO 14 software for SAS.

\section{RESULTS AND DISCUSSION}

Tables 1 show the average physical and chemical properties of the top and subsoil samples collected across the study areas. The mean value of the soil physical properties revealed that the values of the sand contents ranged from $72-83 \%$ at the topsoil $0-15 \mathrm{~cm}$ and $69.5-80.99 \%$ at the subsoil. The value decreased with increasing depth and followed an irregular pattern. Olowoyo et al (2013) attributed the higher content of sand in the surface horizon to the translocation of colloidal clay particles deep into the profile with percolating water and selective erosion and transportation of fine particles to the lower slope position during the heavy downpour. The silt contents of the soil ranged from $7-11.5 \%$ at the topsoil and 7.5 $-11.0 \%$ at the subsoil. An outstanding feature of these soils irrespective of their location is their low to moderate silt content at the surface. According to Adeola and Tubonem (2017), this characteristic distinguished the soils of granite and gneiss rock complex origin from other soils of southwestern Nigeria. The content of silt in the soils was comparatively lower than those of the sand fraction. Adeola and Tubonem (2017) and Fasina et al 2007 also reported that soils mostly derived from basement complexes in southwestern Nigeria had low silt content. The clay content ranged from 10.0- $16.5 \%$ at the topsoil and from $11.5-19.5 \%$ at the subsoil. Generally, the clay content increased with depth to a maximum. A similar trend was observed by Oyebiyi et al (2018) in soils of Ife and Ondo areas of southwestern Nigeria. The lower clay content in the 
surface horizon could be attributed to the sorting of soil material by biological and agricultural activities, clay migration, or surface erosion by run-off or a combination of these (Malgwi et al., 2000). The $\mathrm{pH}$ of the soils studied ranged from 5.98 - 6.23 and it falls within the neutral to very strongly acid class (Oyebiyi et al, 2018). Soil pH was observed to increase or decrease irregularly across the sampled area. Similar trends have been observed and reported by Sharu et al. (2013) and Fasina et al. (2007). According to Sharu et al. (2013), the preferred range of $\mathrm{pH}$ for most crops is 5.5-7.0. Generally, there was a higher accumulation of bases in the surface horizon of the soils and the total exchangeable bases decreased with soil depth except in some cases owing to nutrient bicycling (Ajiboye and Ogunwale, 2010), and it could be due to differential weathering that had taken place or as a result of plant uptake and leaching losses. Unlike in most tropical soils, the exchangeable sites of the soils studied were dominated by exchangeable calcium and magnesium. The soil organic matter (SOM) content ranged from 1.03 to $3.73 \%$ in the soils under investigation at both the topsoil and subsoil and generally with increasing soil depth. Fawole et al (2016) classified percentage SOM into low (0 - 1.5\%), medium $(1.5-2.5 \%)$ and high $(>2.5 \%)$. The SOM content was higher in the soil surface than the subsoil, possibly as a result of more decomposable plant materials on the surface soil and that the surface horizons are the points where decomposition and humification of organic materials take place. The low organic matter obtained may be partly due to high temperature and relative humidity effects, which favour rapid mineralization of organic matter (Fawole et.al, 2016; Fashina et al., 2007). The soil total nitrogen level is critically low with all the values less than $1 \mathrm{~g} / \mathrm{kg}$. The total nitrogen of the surface soils was from 0.05 to $0.19 \%$, and subsurface soils were from 0.05 to $0.12 \%$. The probable reasons for the low value of nitrogen in the soils may be due to the rapid rate of soil organic matter decomposition, high rate of leaching, and loss to soil erosion (Solarin and Ayolagha, 2006). Similar results of very low to low nitrogen values were reported by Fasina et al. (2007) for some soils in southwestern Nigeria. The distribution of the Extractable Micronutrients contents of the soils at both the surface and subsoil was irregular as observed. The concentration of $\mathrm{Fe}$ and $\mathrm{Mn}$ was found to be higher in all the profiles examined, this could either be due to the mineral composition of the underlying rock and the transported materials, uptake of essential nutrients by plant, leaching of exchangeable cations through heavy rainfall, or by erosion or a combination of these factors.

Table 1a: Physical and Chemical properties of various plantations under investigation at Onigambari Forest Reserve (Topsoil)

\begin{tabular}{lllllllllllllllll}
\hline $\begin{array}{l}\text { Plantation5 } \\
\text { Teak 1 }\end{array}$ & Sand & Clay & Silt & Ph & OC & OM & TN & Na & Ca & Mg & K & Fe & Cu & Mn & Zn & p \\
\hline A & 74.5 & 15.0 & 10.5 & 5.92 & 0.66 & 1.14 & 0.06 & 1.23 & 4.29 & 3.95 & 0.10 & 12.00 & 0.30 & 53.3 & 4.8 & 3.97 \\
B & 74.5 & 15.0 & 10.5 & 6.08 & 1.92 & 3.31 & 0.17 & 1.15 & 4.69 & 3.55 & 0.089 & 16.0 & 0.4 & 76 & 4.9 & 12.76 \\
C & 80.5 & 13 & 6.5 & 5.28 & 1.32 & 2.27 & 0.11 & 1.27 & 3.19 & 2.57 & 0.045 & 29 & 0.5 & 60.8 & 3.6 & 6.61 \\
D & 84.5 & 11 & 4.5 & 5.91 & 1.68 & 2.98 & 0.15 & 1.18 & 4.29 & 2.96 & 0.05 & 16 & 0.4 & 56.1 & 4.1 & 5.44 \\
Mean & 78.5 & 13.5 & 8.00 & 5.80 & 1.40 & 2.43 & 0.12 & 1.21 & 4.12 & 3.26 & 0.07 & 18.25 & 0.40 & 61.55 & 4.35 & 7.19 \\
Teak 2 & & & & & & & & & & & & & & & & \\
A & 82.5 & 9 & 8.5 & 5.93 & 0.78 & 1.34 & 0.07 & 1.06 & 1.29 & 2.27 & 0.07 & 12 & 0.6 & 35.8 & 3.3 & 13.71 \\
B & 84.5 & 11 & 4.5 & 6.30 & 0.36 & 0.62 & 0.03 & 1.20 & 0.60 & 1.71 & 0.067 & 55 & 0.7 & 24.9 & 1.1 & 18.35 \\
C & 80.5 & 11 & 8.5 & 5.49 & 0.46 & 0.79 & 0.04 & 1.27 & 1.09 & 2.47 & 0.059 & 14 & 0.7 & 30.6 & 3.2 & 1.17 \\
D & 84.5 & 9 & 6.5 & 6.21 & 0.80 & 1.38 & 0.07 & 1.39 & 0.70 & 1.94 & 0.052 & 36 & 0.5 & 32.5 & 3.1 & 12.85 \\
Mean & 83.00 & 10 & 7 & 5.98 & 0.60 & 1.03 & 0.05 & 1.23 & 0.92 & 2.09 & 0.06 & 29.25 & 0.63 & 30.95 & 2.68 & 11.52 \\
NF & & & & & & & & & & & & & & & & \\
A & 74.5 & 13 & 12.5 & 6.49 & 2.11 & 3.65 & 0.18 & 1.25 & 4.89 & 5.72 & 0.148 & 16 & 0.6 & 77 & 7.3 & 4.65 \\
B & 68.5 & 19 & 12.5 & 5.82 & 3.13 & 5.40 & 0.27 & 1.28 & 4.29 & 5.43 & 0.23 & 16 & 0.5 & 85 & 1.8 & 2.35 \\
C & 72.5 & 17 & 10.5 & 5.48 & 1.64 & 2.82 & 0.14 & 1.34 & 3.09 & 2.76 & 0.104 & 12 & 1.1 & 58.1 & 6.4 & 2.44 \\
D & 72.5 & 17 & 10.5 & 6.71 & 1.76 & 3.03 & 0.15 & 1.33 & 7.78 & 7.17 & 0.208 & 13 & 0.8 & 113 & 9.4 & 1.40 \\
Mean & 72.0 & 16.5 & 11.5 & 6.03 & 2.16 & 3.73 & 0.19 & 1.30 & 5.01 & 5.27 & 0.17 & 14.25 & 0.75 & 83.28 & 6.23 & 2.71 \\
\hline
\end{tabular}

Table 1b: Physical and Chemical properties of various plantations under investigation at Onigambari Forest Reserve (Subsoil)

\begin{tabular}{|c|c|c|c|c|c|c|c|c|c|c|c|c|c|c|c|c|}
\hline FOREST & $\mathrm{pH}$ & $0 . \mathrm{C}$ & O.M & $\mathrm{TN}$ & $\mathrm{Na}$ & $\mathrm{Ca}$ & $\mathrm{Mg}$ & $\mathrm{K}$ & $\mathrm{Fe}$ & $\mathrm{Cu}$ & $\mathrm{Mn}$ & $\mathrm{Zn}$ & $\mathrm{p}$ & Sand & Clay & Silt \\
\hline $\begin{array}{l}\text { andis }(0-15 \mathrm{~cm}) \\
\text { andis }(15-30 \mathrm{~cm})\end{array}$ & $5.95 \mathrm{a}$ & $0.99 \mathrm{~b}$ & $1.72 \mathrm{~b}$ & $\begin{array}{l}0.095 \mathrm{a} \\
0.07 \mathrm{a}\end{array}$ & & & $\begin{array}{l}2.68 b c \\
2.23 \mathrm{c}\end{array}$ & & $\begin{array}{l}23.75 a \\
26.88 \mathrm{a}\end{array}$ & $\begin{array}{l}0.49 \mathrm{a} \\
0.60 \mathrm{a}\end{array}$ & & & & $\begin{array}{l}80.75 \mathrm{a} \\
76.25 \mathrm{ab}\end{array}$ & $\begin{array}{l}11.75 \mathrm{a} \\
14.50 \mathrm{a}\end{array}$ & $\begin{array}{l}7.52 \mathrm{a} \\
8.5 \mathrm{ab}\end{array}$ \\
\hline Natr & $6.15 \mathrm{a}$ & $2.16 \mathrm{a}$ & $3.73 \mathrm{a}$ & $0.19 \mathrm{a}$ & $1.30 \mathrm{a}$ & $5.01 \mathrm{a}$ & $5.27 \mathrm{a}$ & $0.17 \mathrm{a}$ & 14. & a & & 6.2 & & & & $12.0 \mathrm{a}$ \\
\hline Natur & $6.25 \mathrm{a}$ & $1.37 \mathrm{ab}$ & $2.35 \mathrm{ab}$ & $0.12 \mathrm{a}$ & $1.40 \mathrm{a}$ & $2.17 \mathrm{~b}$ & $4.03 \mathrm{ab}$ & $0.11 \mathrm{~b}$ & $20.25 \mathrm{a}$ & $0.50 \mathrm{a}$ & $47.43 \mathrm{~b}$ & $4.63 \mathrm{ab}$ & $5.90 \mathrm{ab}$ & $69.5 c$ & $19.50 \mathrm{a}$ & $11.0 \mathrm{a}$ \\
\hline Mea & 13 & 134 & 29 & 0.12 & 1.32 & 2.89 & 3.55 & & 71 & $8:$ & 56.03 & 4.32 & 71 & 74.63 & 15.44 & 9.75 \\
\hline S.E & 0.11 & 0.24 & 0.41 & 0.02 & 0.1 & 0.27 & 0.36 & 0.01 & 4.53 & 0.11 & 2.43 & 0.84 & 1.83 & 1.53 & 1.64 & 0.93 \\
\hline
\end{tabular}

*Means with same alphabets are not significantly different from one another $(p \leq 0.05) ; *$ S.E $=$ standard error 
Table 2: shows the Physical and chemical characteristics of soils at various depths.

\begin{tabular}{lllllllllllllllll}
\hline $\begin{array}{l}\text { Plantation } \\
\text { Teak 1 }\end{array}$ & Sand & Clay & Silt & $\mathrm{pH}$ & $\mathrm{OC}$ & $\mathrm{OM}$ & $\mathrm{TN}$ & $\mathrm{Na}$ & $\mathrm{Ca}$ & $\mathrm{Mg}$ & $\mathrm{K}$ & $\mathrm{Fe}$ & $\mathrm{Cu}$ & $\mathrm{Mn}$ & $\mathrm{Zn}$ & $\mathrm{p}$ \\
\hline A & 62.5 & 29 & 8.5 & 6.09 & 0.92 & 1.58 & 0.08 & 1.36 & 2.39 & 3.65 & 0.067 & 19 & 0.5 & 50.4 & 2.2 & 0.21 \\
B & 68.5 & 17 & 14.5 & 6.20 & 1.40 & 2.41 & 0.12 & 1.34 & 3.39 & 2.06 & 0.111 & 13 & 0.9 & 100 & 4.4 & 5.18 \\
C & 80.5 & 13 & 6.5 & 6.22 & 0.70 & 1.20 & 0.06 & 1.17 & 2.39 & 1.97 & 0.052 & 25 & 0.4 & 56.8 & 3.8 & 3.57 \\
D & 74.5 & 13 & 12.5 & 6.09 & 1.12 & 1.93 & 0.10 & 1.23 & 3.29 & 2.70 & 0.45 & 13 & 0.4 & 59.9 & 2.6 & 2.55 \\
Mean & 71.5 & 18 & 10.5 & 6.15 & 1.035 & 1.78 & 0.09 & 1.275 & 2.865 & 2.595 & 0.17 & 17.5 & 0.55 & 66.775 & 3.25 & 2.888 \\
Teak 2 & & & & & & & & & & & & & & & & \\
A & 80.5 & 13 & 6.5 & 5.76 & 0.82 & 1.41 & 0.07 & 1.67 & 0.89 & 1.84 & 0.037 & 20 & 0.6 & 31.3 & 3.7 & 10.44 \\
B & 84.45 & 11 & 4.5 & 6.25 & 0.32 & 0.55 & 0.03 & 1.32 & 0.30 & 1.58 & 0.045 & 62 & 0.6 & 22.5 & 1.1 & 26.38 \\
C & 74.5 & 11 & 14.5 & 6.05 & 0.38 & 0.65 & 0.03 & 1.18 & 0.89 & 1.88 & 0.030 & 16 & 1.1 & 22.2 & 2.3 & 13.64 \\
D & 84.5 & 11 & 4.5 & 6.10 & 0.82 & 1.41 & 0.07 & 1.41 & 1.40 & 2.11 & 0.052 & 47 & 0.3 & 34.1 & 3.1 & 2.93 \\
Mean & 80.99 & 11.5 & 7.5 & 6.04 & 0.59 & 1.01 & 0.05 & 1.40 & 0.87 & 1.85 & 0.04 & 36.25 & 0.65 & 27.53 & 2.55 & 13.35 \\
NF & & & & & & & & & & & & & & & \\
A & 74.5 & 11 & 14.5 & 6.85 & 1.22 & 2.10 & 0.11 & 1.27 & 1.70 & 3.65 & 0.089 & 34 & 0.3 & 48.4 & 6.2 & 3.58 \\
B & 66.5 & 27 & 6.5 & 6.02 & 1.66 & 2.86 & 0.14 & 1.88 & 2.20 & 5.63 & 0.148 & 24 & 0.8 & 48.8 & 3.1 & 12.32 \\
C & 70.5 & 21 & 8.5 & 5.72 & 0.86 & 1.48 & 0.07 & 1.18 & 2.30 & 2.43 & 0.05 & 14 & 0.3 & 49.4 & 4.6 & 0.92 \\
D & 66.5 & 19 & 14.5 & 6.44 & 1.72 & 2.96 & 0.15 & 1.27 & 2.49 & 4.40 & 0.156 & 9 & 0.6 & 43.1 & 4.6 & 6.78 \\
Mean & 69.5 & 19.5 & 11.0 & 6.26 & 1.37 & 2.35 & 0.12 & 1.40 & 2.17 & 4.03 & 0.11 & 20.25 & 0.50 & 47.43 & 4.63 & 5.90 \\
\hline
\end{tabular}

Relationship between the soils' physical and chemical properties: Table 2 shows the physical and chemical characteristics of soils at various depths under the Tectonia grandis vegetation and Natural Forest. For Tectonia grandis; the $\mathrm{pH}$, although not significantly different, increased from 5.95 (surface) to 6.15 (subsurface) while organic carbon OC decreased by $83 \%$, total nitrogen also decreased by $74 \%$, while about $81 \%$ decrease was observed for Organic matter from surface to subsurface. The concentrations of exchangeable cations also decreased with depth; $\mathrm{Ca}$ content at both depths were not significantly different from one another while $\mathrm{K}$ and $\mathrm{Mg}$ content was slightly higher at the surface compared to the subsurface. Zinc concentrations also decreased with depth, with surface depth having a slightly higher amount. Fe, Mn and P increased with depth while sand content decreased significantly, clay content was not significantly different but higher amounts were observed at the subsurface.

Moreover, for natural forest; the $\mathrm{pH}$, although not significantly different, increased from 6.15 (surface) to 6.25 (subsurface) while organic carbon OC decreased by $63 \%$, total nitrogen also decreased by $64 \%$, while about $63 \%$ decrease was observed for Organic matter from surface to subsurface. The concentrations of exchangeable cations also decreased with depth; $\mathrm{Ca}$ content at both depths were significantly different from one another while $\mathrm{K}$ and $\mathrm{Mg}$ content was significantly higher at the surface compared to the subsurface. Zinc concentrations also decreased with depth with surface depth having a slightly higher amount (6.23) compared to subsurface (4.63). Fe and P increased with depth while sand content decreased significantly, clay content was not significantly different but higher amounts were observed at the subsurface. And lower amount was observed for silt.

Conclusion: In this study, the aim was to assess the impact of management techniques for sustaining the forest soils nutrient status using a comparative study of soil chemical and physical properties of different forest types in Onigambari Forest-Reserve. The physical and chemical properties of soils of the natural forest were higher than that of Tectonia grandis. Therefore, it is important to re-examine the management practices for Tectonia grandis vegetation in order to improve soil properties. Therefore, we suggest reduction of human activities and controlled felling of this species should be encouraged.

\section{REFERENCES}

Adeola, AJ; Tubonem ET (2017). Mineralogical and Geochemical Trends in the Residual Soils above Basement Rocks in Ore Area, Southwestern Nigeria. $J G G ; 9(3)$ : 42-58

Agyarko, K; Dartey, E; Kuffour, RA; Sarkodie PA (2014). Assessment of Trace Elements Levels in Sediment and Water in Some Artisanal and Small-Scale Mining (ASM) Localities in Ghana. Curr. World Environ. 9(1): 07-16.

Ajiboye, GA; Ogunwale, JA (2010). Characteristics and classification of soils develop over talc at Ejiba, Kogi State, Nigeria. NJSS. 20 (1): 16-25.

Akinyemi, GO; Ige, PO; Smith, AS (2012). Evaluating Crown-Diameter Prediction Models for Terminalia superba (Engl. \& Diels) in Onigambari Forest Reserve, Nigeria. Journal of Forestry Research and Management. 9: 14-25. 
Aluko, AP (1993). Soil properties and nutrient distribution in Terminalia superba stands of different age series grown in two soil types of southwestern Nigeria. For. Ecol. Manag. 58: 153161.

Bouyoucos, GJ (1962). Hydrometer method improved for making particle size analysis of soils. Agron. J. 54: 464-465.

Bray, RH; Kurtz, LT (1945). Determination of total organic and available forms of phosphorus in soils. Soil Sci. 59: 39-45.

Bremner, JM (1995). Total Nitrogen. In: Sparks, D.L., Ed., Methods of Soil Analysis, Part 3, Chemical Methods, Soil Science Society of America and ASA, Madison, 1123-1184.

Emenyonu, CA; Orebiyi, JS; Eze, CC; Odii, MA; Onyemauwa, CS; Eririogu, IH (2015). Analysis of Land Use Cover Change In Western Niger Delta: A Panacea For Agricultural Land Reduction. NJAE. 5(1): 92-99

Fasina, AS; Omolayo FO; Falodun, AA; Ajayi, OS (2007). Gramitic derived soils in humid forest of southwestern Nigeria-Genesis, classification and sustainable management. Am. Eur. J. Agric. Environ. Sci. 2: 189-95.

Fawole, O; Ojetade, JO; Amusan AA (2016). Genesis and Classification of Soils on a Toposequence Underlain by Mica Schist in Ife Area, Southwestern Nigeria. GJSFR. 16(7): 30-42

Haque, MI; Basak, R (2017). Land cover change detection using GIS and remote sensing techniques: A spatio-temporal study on Tanguar Haor, Sunamganj, Bangladesh. Egypt. J. Remote. Sens. Space Sci. 20(2): 251263.

Larinde, SL; Olasupo OO (2011). Socio-Economic Importance of Fuelwood Production in Gambari Forest Reserve Area, Oyo State, Nigeria. JASR. 11(1): 201-210.

Malgwi, WB; Ojanuga, AG; Chude, VO; Kparmwang, T; Raji, BA (2000). Morphological and physical properties of some at Samaru, Zaria, Nigeria. Nig. J. Soil Res. 1: 58-64.

Njike, C; Igbokwe, JI; Orisakwe, KU (2011). "Analysis of Landuse and Landcover Changes of Aba Urban Using Medium Resolution Satellite
Imageries". FIG Working Week 2011 Bridging the Gap between Cultures Marrakech, Morocco, May 18-22. PP 1-14

Nwite, JN; Alu MO (2017). Carbon sequestration and assessment of fertility status of soil under different land uses for agronomic potentials in Abakaliki South Eastern Nigeria. Afr. J. Agric. Res. 12(11): 871-880.

Olowoyo, JO; Ofoezie, IE; Amusan, AA (2013). Impact of agricultural activities on phosphorus in streams draining into Opa Reservoir Ile Ife, Nigeria, Int. J. Environmental Engineering. 5(1): 41-51.

Opeyemi, ZA (2008). Monitoring the growth of settlements in Ilorin, Nigeria (A GIS and Remote Sensing Approach). The International Archives of the Photogrammetry, Remote Sens. Spatial Info. Sci., 37: 225-232.

Oswald, FL; Mitchell, G; Blanton, H; Jaccard, J; Tetlock, PE (2013). Predicting ethnic and racial discrimination: A meta-analysis of IAT criterion studies. Journal of Personality and Social Psychology, 105(2): 171-192.

Oyebiyi, OO; Ojetade, JO; Muda, SA; Amusan AA (2018). Comparative study of three methods of determining cation exchange capacity of three major soils in the rainforest region of Southwestern Nigeria. Commun Soil Sci Plant Anal. 49(1): 1-7.

Sharu, MB; Yakubu, M; Noma, SS; Tsafe, AI (2013). Characterization and Classification of Soils on an Agricultural landscape in Dingyadi District, Sokoto State, Nigeria. NJBAS. 21(2): 137-147

Solarin, LO; Ayolagha, GA (2006). Characterisation and classification of cement dust-polluted soils in Sagamu area, Southwestern Nigeria. NJSS. 16(1): 24-34.

Thuo AD (2013). Impacts of Urbanization on Land Use Planning, Livelihood and Environment in the Nairobi Rural-Urban Fringe, Kenya. IJSTR. 2(7): 70-79. 